\title{
Antidiabetic activity, glucose uptake stimulation and a-glucosidase inhibitory effect of Chrysophyllum cainito L. stem bark extract
}

Hau Van Doan, Siriporn Riyajan, Roongtip lyara and Nuannoi Chudapongse*

\begin{abstract}
Background: Chrysophyllum cainito L., a tropical fruit tree, has been used as an alternative medicine for the treatment of diabetic patients in many countries. However, there is very limited scientific rationale for this medical use. The present study aimed to evaluate the antidiabetic activity of the extract from C. cainito stem bark and the possible mechanisms underlying this activity.

Methods: Phytochemistry and in vitro antioxidant capacity of the extract were studied. Hypoglycemic activity of the extract was examined in normal and alloxan-induced diabetic mice. The effect of $C$. cainito extract on glucose absorption and glucose uptake were conducted using mouse isolated jejunum and abdominal muscle, respectively. Finally, an in vitro effect of $C$. cainito extract on a-glucosidase activity was evaluated.

Results: C. cainito extract possessed a strong antioxidant activity comparable to the ascorbic acid and butylated hydroxytoluene. The extract at $500 \mathrm{mg} / \mathrm{kg}$ significantly reduced the area under curve of blood glucose level in oral glucose tolerance test in normal mice. In alloxan-induced diabetic model, similar to glibenclamide, a single dose of the extract significantly decreased fasting blood glucose level from $387.17 \pm 29.84 \mathrm{mg} / \mathrm{dl}$ to $125.67 \pm 62.09 \mathrm{mg} / \mathrm{dl}$ after $6 \mathrm{~h}$ of administration. From the isolated jejunum experiment, the extract at any doses used did not inhibit glucose absorption. However, the extract at $50 \mathrm{\mu g} / \mathrm{ml}$ significantly increased the amount of glucose uptake by abdominal muscles in the presence of insulin $(P<0.05)$. Lastly, it was found that the extract produced stronger inhibition of a-glucosidase activity $\left(I C_{50}=1.20 \pm 0.09 \mu \mathrm{g} / \mathrm{ml}\right)$ than acarbose $\left(\mathrm{IC}_{50}=198.17 \pm 4.74 \mu \mathrm{g} / \mathrm{ml}\right)$.

Conclusion: Direct evidence of antidiabetic activity of $C$. cainito stem bark with possible modes of action, glucose uptake stimulation and a-glucosidase inhibitory effect, was reported for the first time herein. These data support the potential use of this plant for the treatment of diabetic patients.
\end{abstract}

Keywords: Chrysophyllum cainito, Antidiabetic activity, Glucose uptake, a-glucosidase, Alloxan

\section{Background}

Diabetes mellitus, one of the most common metabolic disorders, has been reported to affect approximately 415 million people worldwide in 2015 and the number of cases has been estimated to increase to 642 millions in 2040 [1]. Chronic hyperglycemic patients have been living with a high risk of macrovascular complications (e.g., coronary artery disease, peripheral arterial disease,

* Correspondence: nuannoi@sut.ac.th

School of Preclinical Sciences, Institute of Science, Suranaree University of Technology, Nakhon Ratchasima 30000, Thailand and/or stroke) and microvascular complications (e.g., retinopathy, nephropathy, and neuropathy) [2]. Being supplied with high blood glucose, cells can generate the formation of free radicals and reactive oxygen species. In turn, an overload of free radicals can damage cellular macromolecules including lipid, protein and nucleic acids leading to the progression of diabetes and the development of its complications. Therefore, the antioxidant therapy is one of the important therapeutic strategy in diabetes management [3]. Plants have been widely accepted that they provide natural antioxidant compounds

(c) The Author(s). 2018 Open Access This article is distributed under the terms of the Creative Commons Attribution 4.0 International License (http://creativecommons.org/licenses/by/4.0/), which permits unrestricted use, distribution, and reproduction in any medium, provided you give appropriate credit to the original author(s) and the source, provide a link to the Creative Commons license, and indicate if changes were made. The Creative Commons Public Domain Dedication waiver (http://creativecommons.org/publicdomain/zero/1.0/) applies to the data made available in this article, unless otherwise stated. 
$[4,5]$. In addition, plant products and their derivatives also possess many other pharmacological activities, such as anti-inflammatory, antimicrobial, anticancer and antidiabetic activity. Thus, traditional medicines have been proved to be a vital source of future drugs to counteract many diseases including diabetes mellitus [6].

Chrysophyllum cainito L. (commonly known as Star Apple) is a tropical fruit tree of which many biological activities have been demonstrated. The documented benefits of $C$. cainito include antihypertensive, anti-inflammatory [7], antioxidant and wound healing [8], antibacterial [9] and antidiabetic activity $[10,11]$. The stem bark decoction has been traditionally used as tonic, stimulant, antidiarrheals [12] and antidiabetics [13]. Although several parts of $C$. cainito, such as fruit, leaf and stem, have been used as alternative medicines for the treatment of diabetic patients in many countries, there is limited pharmacological basis for this therapeutic application. The present study was carried out to evaluate the antidiabetic activity of the aqueous extract of $C$. cainito stem bark in animal models. In addition, the effects on glucose absorption, glucose uptake and $\alpha$-glucosidase activity were also examined as the possible mechanisms underlying antidiabetic property of the extract.

\section{Methods}

\section{Chemicals}

2,2-Diphenyl-1-picrylhydrazyl (DPPH), 2,2'-Azino-bis (3-ethylbenzothiazoline-6-sulfonic acid) diammonium salt (ABTS), 2,4,6-tripyridyl-s-triazine (TPTZ), Peroxidaseglucose oxidase (PGO) enzyme, $\alpha$-glucosidase, alloxan monohydrate were purchased from Sigma-Aldrich (MO, USA). Folin-Ciocalteu reagent was purchased from Carlo-Erba (Val de Reuil Cedex, France). Blood glucose test strips were purchased from Terumo (Tokyo, Japan).

\section{Plant extraction}

The stem bark of C. cainito was collected from Mo Cay Nam district, Ben Tre, Vietnam. Plant verification was performed by Dr. Santi Watthana, a plant taxonomist, School of Biology, Institute of Science, Suranaree University of Technology, Thailand. Voucher specimens of leaf, fruit, flowers, and stem was stored at Suranaree University of Technology Botanical Garden under collected number H.DOAN-1. The bark was dried under the shade for a week before ground. In this study, water was chosen as an extraction solvent because water formulations are safe for human consumption compared to other organic solvents. It also increases bioavailability of active compounds. Furthermore, water maceration and decoction of this plant have been used by Vietnamese for treatment of diabetic patients. We have chosen simple maceration rather than decoction to prevent chemical degradation from high temperature. Briefly, $50 \mathrm{~g}$ of ground material were shaken with $200 \mathrm{ml}$ of deionized water at room temperature for $2 \mathrm{~h}$. The process was repeated four times. The combined extract was centrifuged at $5000 \mathrm{rpm}$ for $15 \mathrm{~min}$ to remove solid residue. The supernatant was evaporated and dried by lyophilizer. The extract of C. cainito stem bark (CE) was kept at $-20{ }^{\circ} \mathrm{C}$ until used for the experiments.

\section{Phytochemical screening and total phenolic content determination}

Phytochemical screening for tannin, phenols, alkaloids, flavonoids, saponin, steroids and glycosides were conducted as previously described [14]. The presence of terpenoids was also examined [15].

Total phenolic content was determined by FolinCiocalteu reagent using gallic acid as a standard. Briefly, after incubation at room temperature for $30 \mathrm{~min}$, the absorbance of the mixture of $\mathrm{CE}$ and Folin-Ciocalteu reagent was measured at $750 \mathrm{~nm}$ by spectrophotometer. Total phenolic content of CE was expressed as mg of gallic acid equivalents (GAE) per gram of dried extract [16].

\section{In vitro antioxidant activity $D P P H$ radical scavenging activity}

To perform DPPH assay, one milliliter of various concentrations of CE $(0-25 \mu \mathrm{g} / \mathrm{ml})$ was mixed with $2 \mathrm{ml}$ of $0.1 \mathrm{mM}$ DPPH in methanol and left standing for $1 \mathrm{~h}$ at room temperature in the dark. The absorbance was measured at $515 \mathrm{~nm}$. Percentage of inhibition was calculated using the equation below. The antioxidant activity was expressed by the concentration required for $50 \%$ of scavenging of free radical $\left(\mathrm{IC}_{50}\right)$ [17].

$\%$ inhibition $=\left[\left(\right.\right.$ Absorbance $_{\text {control }}-$ Absorbance $\left._{\text {sample }}\right) /$

Absorbance $\left._{\text {control }}\right] \times 100$

\section{ABTS radical scavenging activity}

The scavenging activity of $\mathrm{CE}$ against $\mathrm{ABTS}^{*}$ was measured as previously described with minor modifications [16]. ABTS radical cation (ABTS*) was produced by adding $14 \mathrm{mM}$ ABTS solution to $4.9 \mathrm{mM}$ potassium persulfate solution $(1: 1 ; v / v)$ for $16 \mathrm{~h}$ in the dark at room temperature. The $150 \mu \mathrm{l}$ of $\mathrm{CE}$ at various concentrations $(0-25 \mu \mathrm{g} / \mathrm{ml})$, ascorbic acid or butylated hydroxytoluene (BHT) was added to $2850 \mu \mathrm{l}$ of diluted ABTS ${ }^{*}$ solution, mixed and then incubated in the dark for 6 min. Finally, the absorbance of the reaction mixture was measured at $734 \mathrm{~nm}$. The radical scavenging activity of CE was expressed by $\mathrm{IC}_{50}$ value. 


\section{Ferric reducing antioxidant power (FRAP) assay}

FRAP assay was performed to investigate the reducing power of CE [18]. The absorbance of the resulting mixture was measured at $593 \mathrm{~nm}$. The standard calibration curve was created using $\mathrm{FeSO}_{4} \cdot 7 \mathrm{H}_{2} \mathrm{O}$. The FRAP capacity of the extract was expressed as $\mathrm{mM} \mathrm{Fe}{ }^{2+}$ per gram extract.

\section{Experimental animals}

Male Jcl:ICR mice of 6-week old (28-34 g), obtained from Nomura Siam International Co., Ltd., Bangkok, Thailand, were used in this study. Mice were housed in stainless steel cages lined with wood shavings at Laboratory Animal Facility, Suranaree University of Technology, under standard condition of $25 \pm 2{ }^{\circ} \mathrm{C}, 45-50 \%$ relative humidity and 12-h light/dark cycle. Normal food and water were given ad libitum. The experiments were performed after 7 days of acclimatization. The extract was dissolved in distilled water and was administered to animal using oral gavage method. All mice were sacrificed by $\mathrm{CO}_{2}$ inhalation at the end of experiment and for tissue collection. All procedures were approved and conducted following the guidelines of the Institutional Animal Care and Use Committee, Suranaree University of Technology, Thailand (Approval number No. 1/2561).

\section{Oral glucose tolerance test in normal mice}

The effect of $\mathrm{CE}$ on blood glucose level was first evaluated via oral glucose challenge. Six-hour fasted normal mice were randomly divided into 3 different groups $(n=6)$ as the following.

Group 1: normal mice + deionized water

Group 2: normal mice $+500 \mathrm{mg} / \mathrm{kg} \mathrm{CE}$

Group 3: normal mice $+10 \mathrm{mg} / \mathrm{kg}$ glibenclamide (Daonil ${ }^{\oplus}$, Jakarta, Indonesia)

All mice were pretreated with drugs prior to the oral glucose administration at the dose $2 \mathrm{~g} / \mathrm{kg}$ ( $2 \mathrm{~h}$ for CE and deionized water; 30 min for glibenclamide based on the onset of action from our preliminary study). Blood glucose level was monitored at 0, 30, 60 and $120 \mathrm{~min}$ from small incision of tail tip using Medisafe ${ }^{\bullet}$ EX glucose meter. The area under the curve was calculated using the same formula in the previous report [19].

\section{Hypoglycemic test in alloxan-induced diabetic mice}

Overnight fasted mice were received an intraperitoneal injection of $130 \mathrm{mg} / \mathrm{kg}$ of alloxan monohydrate dissolved in cold $0.85 \%$ saline solution to induce type 2 diabetes [20]. Diabetic induction was checked after 3 days of alloxan injection. Mice showed glucose level greater than $200 \mathrm{mg} / \mathrm{dl}$ (survived without insulin) was considered as type 2 diabetic mice [21] and used for the experiment. Mice were randomly divided into 4 groups as follow.

Group 1: normal mice + deionized water $(n=6)$
Group 2: diabetic mice + deionized water $(n=6)$

Group 3: diabetic mice $+500 \mathrm{mg} / \mathrm{kg} \mathrm{CE}(n=6)$

Group 4: diabetic mice $+10 \mathrm{mg} / \mathrm{kg}$ glibenclamide $(n=5)$

After the single dose of drug administration, blood glucose levels were determined at $0,1,2,4$ and $6 \mathrm{~h}$ to evaluate acute hypoglycemic effect of the extract as described in the previous study [22].

\section{Effect of the extract on glucose absorption}

The inhibitory effect of CE on glucose absorption was investigated using isolated mouse jejunum. The jejunum was isolated from normal mouse and placed in oxygenated Kreb-Henseleit solution (composition in $\mathrm{g} / \mathrm{l} ; \mathrm{NaCl} 6.92$, $\mathrm{KCl} 0.35, \mathrm{MgSO}_{4} .7 \mathrm{H}_{2} \mathrm{O} 0.29, \mathrm{CaCl}_{2} 0.28, \mathrm{KH}_{2} \mathrm{PO}_{4}$ 0.16, $\mathrm{NaHCO}_{3}$ 2.1, and D-glucose 1.4), pH 7.4. The jejunum was cut into $6 \mathrm{~cm}$ long segments, tied edges, everted and filled with Kreb-Henseleit solution. The sacs were incubated in $10 \mathrm{ml}$ of Kreb-Henseleit solution containing each of the following substances CE (25 and $50 \mu \mathrm{g} / \mathrm{ml}$ ) or acarbose $(1 \mathrm{mg} / \mathrm{ml})$ for $1 \mathrm{~h}$ in the presence of carbogen at $37^{\circ}$ C. Glucose concentrations inside the sacs were determined using PGO enzyme. Ten $\mu$ l of diluted buffer was interacted with $190 \mu \mathrm{l}$ of PGO enzyme solution in a microtitter plate. The reaction mixture was incubated at $37{ }^{\circ} \mathrm{C}$ in the dark for $30 \mathrm{~min}$. The intensity of the brown color was measured at $450 \mathrm{~nm}$ using spectrophotometer. The concentration of glucose was calculated using standard curve of D-glucose. The amount of glucose absorption was calculated using the following formula [23].

$$
\begin{aligned}
\text { Amount of glucose absorbed } & =\text { (amount of glucose after } \\
& \text {-amount of glucose before }) \\
& \text { /g of jejunum }
\end{aligned}
$$

\section{Effect of the extract on glucose uptake}

Glucose uptake by mouse abdominal muscle was measured as previously described [24]. Briefly, after animals were sacrificed, abdominal muscles were removed and soaked in the Kreb's-Ringer bicarbonate (KRB) buffer, $\mathrm{pH} 7.4$ with continuously supply of carbogen for $10 \mathrm{~min}$. The muscle was then incubated with KRB buffer containing $200 \mathrm{mg} / \mathrm{dl}$ of D-glucose, CE 25 or $50 \mu \mathrm{g} / \mathrm{ml}$ with or without insulin $(100 \mathrm{mU} / \mathrm{ml})$ for $30 \mathrm{~min}$. Then, buffer was collected and analyzed for the remaining glucose using PGO enzyme as described in the previous section. The amount of glucose uptake was calculated by the formula below.

$$
\begin{aligned}
\text { Amount of glucose uptake } & =(\text { amount of glucose before } \\
& - \text { amount glucose after }) \\
& \text { /g of muscle }
\end{aligned}
$$

\section{Examination of the effect on a-glucosidase activity}

The $\alpha$-glucosidase inhibitory activity was measured as described previously [16]. Briefly, a mixture of $10 \mu \mathrm{l}$ of 
$0.25 \mathrm{U} / \mathrm{ml} \alpha$-glucosidase (Sigma-Aldrich, USA), $50 \mu \mathrm{l}$ of $0.1 \mathrm{M}$ potassium phosphate buffer $(\mathrm{pH} 6.8)$ and $20 \mu \mathrm{l}$ of various concentrations of the extract or the $\alpha$-glucosidase inhibitor acarbose (Fluka, USA) was incubated at $37{ }^{\circ} \mathrm{C}$ for $10 \mathrm{~min}$. Then, $10 \mu \mathrm{l}$ of $5 \mathrm{mM}$ p-nitrophenyl- $\alpha$-D-glucopyranoside (PNPG) was added and further incubated for $30 \mathrm{~min}$. To terminate the reaction, $50 \mu \mathrm{l}$ of $0.1 \mathrm{M} \mathrm{Na}_{2} \mathrm{CO}_{3}$ was added. The absorbance was measured at $405 \mathrm{~nm}$ optically by using a spectrophotometer. Results were expressed as the concentration where the activity of $\alpha$-glucosidase is inhibited by $50 \%\left(\mathrm{IC}_{50}\right)$.

\section{Statistical analysis}

Each experiment was repeated at least 3 times and the result values were expressed as mean \pm SEM.The comparisons between means were done using One way- or Two way-ANOVA followed by Student-Newman-Keuls. A value of $P<0.05$ was considered as statistically significant differences.

\section{Results}

\section{Phytochemistry and total phenolic content}

The results of extract yield and phytochemicals screening were presented in Table 1. In this study, extract yield of $C$. cainito stem bark prepared by maceration method using water was $11.22 \pm 0.54 \%$. The phytochemical screening revealed the presence of phenols, tannin, glycosides, terpenoids, and saponin but the absence of flavonoids, alkaloids, and steroids. Total phenolic compounds found in the extract was $871.75 \pm 10.41 \mathrm{mg}$ GAE/g extract (Table 2).

\section{Antioxidant activity}

To access the antioxidant activity of the extract, DPPH, ABTS free radical scavenging and FRAP assay were performed. The concentrations of $\mathrm{CE}$ were varied from

Table 1 Phytochemical screening and yield of the aqueous extract of C. cainito stem bark

\begin{tabular}{ll}
\hline Test for & Results \\
\hline Phytochemistry & + \\
Phenols & + \\
Tannins & + \\
Glycosides & + \\
Terpenoids & + \\
Saponin & - \\
Flavonoids & - \\
Steroids & - \\
Alkaloids & $11.22 \pm 0.54^{\mathrm{a}}$ \\
Yield (\%) &
\end{tabular}

+ present; - absent

${ }^{a}$ Value is expressed as mean $\pm \operatorname{SEM}(n=3)$
0 to $25 \mu \mathrm{g} / \mathrm{ml}$. The extract showed the maximum radical scavenging activity in the highest experimental concentration by $92 \%$ in DPPH assay and $99 \%$ in ABTS assay (Fig. 1). The $\mathrm{IC}_{50}$ values found for $\mathrm{CE}$, ascorbic acid, and BHT from DPPH and ABTS assays were presented in Table 2. The reducing potential of CE was determined using $\mathrm{FeSO}_{4}$ standard curve. The FRAP value of $\mathrm{CE}$ was $291.56 \pm 3.25 \mathrm{mM} \mathrm{Fe}^{2+}$ equivalent per gram of dried extract (Table 2).

\section{Oral glucose tolerance test in normal mice}

The results of the oral glucose tolerance test in normal mice are shown in Fig. 2. As seen in Fig. 2a, the initial blood glucose levels of all groups prior to drug administration were no difference. The blood glucose levels after glucose loading reached a peak at $30 \mathrm{~min}$ and decreased subsequently over time, in all groups. It was found that $\mathrm{CE}$ or glibenclamide had significantly improved glucose tolerance in normal mice. Mice received CE $(500 \mathrm{mg} / \mathrm{kg})$ and glibenclamide $(10 \mathrm{mg} / \mathrm{kg})$ noticeably suppressed the elevation of glucose after $30 \mathrm{~min}$ of glucose load compared to control group $(P<0.05)$. In addition, the area under the curve (AUC) was significantly reduced in both treated groups when compared to control mice (Fig. 2b).

\section{Antidiabetic effect of $C$. cainito extract in alloxan-diabetic mice}

Fig. 3 shows kinetics of blood glucose observed during the period of experiment. In this study, alloxan injection destroyed pancreatic $\beta$ cells and reduced insulin secretion leading to an elevated blood glucose level compared to normal control mice. The extract and glibenclamide started to suppress the rise of blood glucose in diabetic mice after $2 \mathrm{~h}$ of treatment, but not statistically significant. However, after $4 \mathrm{~h}$ and longer blood glucose levels of the $\mathrm{CE}$ and glibenclamide groups declined significantly more than the diabetic control group $(P<0.05)$.

\section{Effect of $C$. cainito extract on glucose absorption}

The everted sacs of the small intestines from mice were used for investigating the inhibitory effect of $\mathrm{CE}$ on glucose absorption ex vivo. The results shown in Fig. 4 indicated that the extract at the experimental concentrations $(25$ and $50 \mu \mathrm{g} / \mathrm{ml})$ did not inhibit glucose absorption when compared to control. In contrast, acarbose at $1 \mathrm{mg} / \mathrm{ml}$ profoundly suppressed glucose absorption by everted sacs $(P<0.05)$.

\section{Effect of $C$. cainito extract on glucose uptake}

The effect of CE on glucose uptake is presented in Fig. 5. In normal group, low glucose uptake was found in the absence of insulin. Addition of insulin to the KRB buffer increased the glucose uptake significantly $(P<0.05)$. This 
Table 2 Total phenolic content and antioxidant activities of C. cainito stem bark extract

\begin{tabular}{|c|c|c|c|c|}
\hline & $\begin{array}{l}\text { DPPH } \\
\mathrm{IC}_{50}(\mu \mathrm{g} / \mathrm{ml})\end{array}$ & $\begin{array}{l}\text { ABTS } \\
\mid C_{50}(\mu \mathrm{g} / \mathrm{ml})\end{array}$ & $\begin{array}{l}\text { FRAP } \\
\left(\mathrm{mM} \mathrm{Fe}{ }^{2+} / \mathrm{g} \text { extract) }\right.\end{array}$ & $\begin{array}{l}\text { Phenolic Content } \\
\text { (mg GAE/g CE) }\end{array}$ \\
\hline$\overline{C E}$ & $4.66 \pm 0.14^{*}$ & $2.10 \pm 0.06^{\#}$ & $291.56 \pm 3.25$ & $871.75 \pm 10.41$ \\
\hline $\mathrm{AA}$ & $3.49 \pm 0.12$ & $1.86 \pm 0.03$ & - & - \\
\hline $\mathrm{BHT}$ & $4.68 \pm 0.03$ & $5.07 \pm 0.19$ & - & - \\
\hline
\end{tabular}

The values are expressed as mean \pm SEM, $n=3$. CE, AA, BHT were abbreviations of $C$. cainito extract, ascorbic acid and butylated hydroxytoluene, respectively ${ }^{*} P<0.05$ compared with AA; ${ }^{\#} P<0.05$ compared with BHT by one-way ANOVA followed by Student-Newman-Keuls as post hoc test

effect was also observed in all experiments when compared to the non-insulin treated groups. The results showed that treatment of $\mathrm{CE}$ at $50 \mu \mathrm{g} / \mathrm{ml}$ with insulin significantly increased glucose uptake from $7.86 \pm 0.52$ (control) to $9.45 \pm 0.82 \mathrm{mg} / \mathrm{g}$ tissue. However, without insulin, $\mathrm{CE}$ at the doses used had no significant effect on glucose uptake.

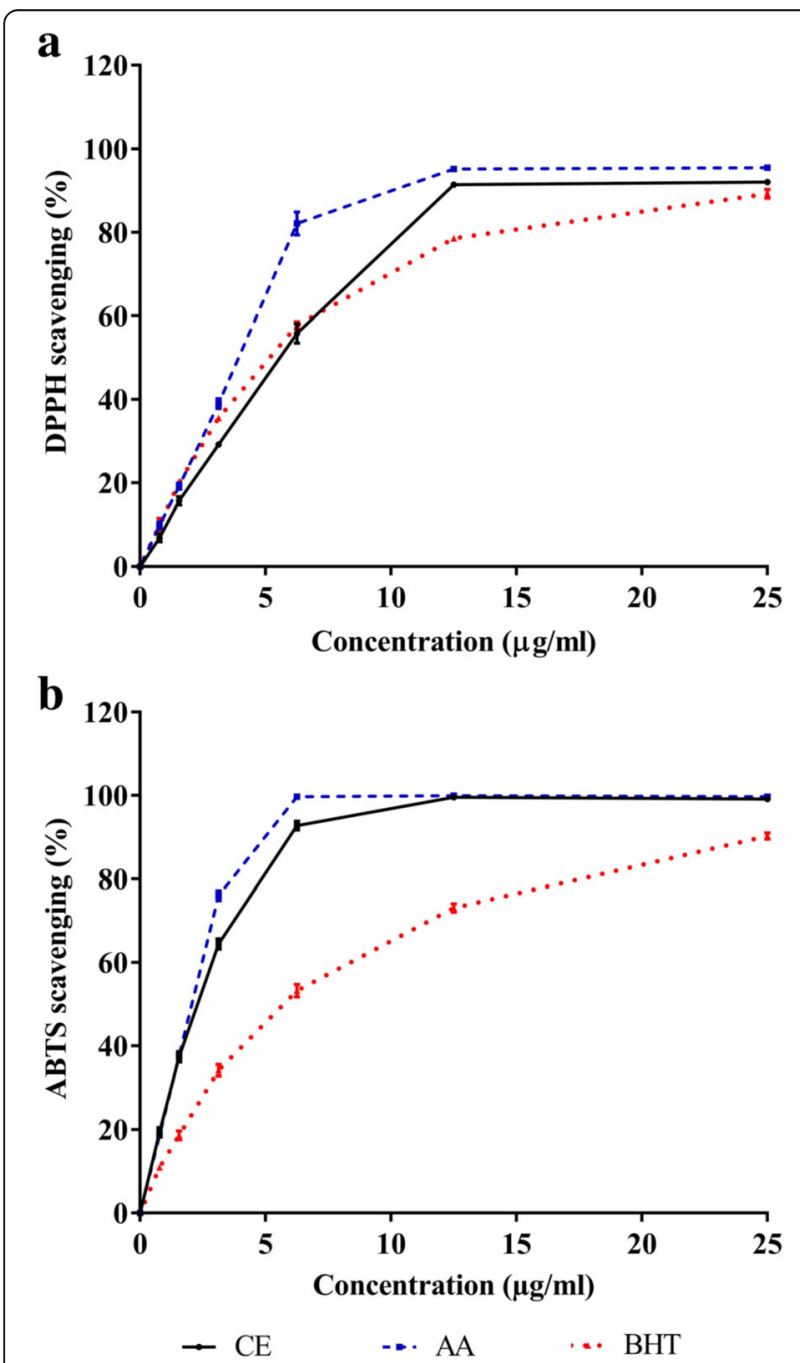

Fig. 1 Antioxidant activity of $C$. cainito extract. Panel $\mathbf{a}$ and $\mathbf{b}$ are the results from DPPH and ABTS) radical scavenging methods, respectively. The values are expressed as mean $\pm \mathrm{SEM}, n=3$. AA: ascorbic acid; BHT: butylated hydroxytoluene; CE: C. cainito extract

\section{a-Glucosidase inhibitory effect of $C$. cainito extract}

$\alpha$-Glucosidase enzyme is one of the medication targets in diabetic management. The enzyme is involved in digestion of polysaccharide into monosaccharide that can be absorbed by the intestine. In this study, $\alpha$-glucosidase isolated from Saccharomyces cerevisiae was chosen as the target enzyme. The aqueous extract from $C$. cainito
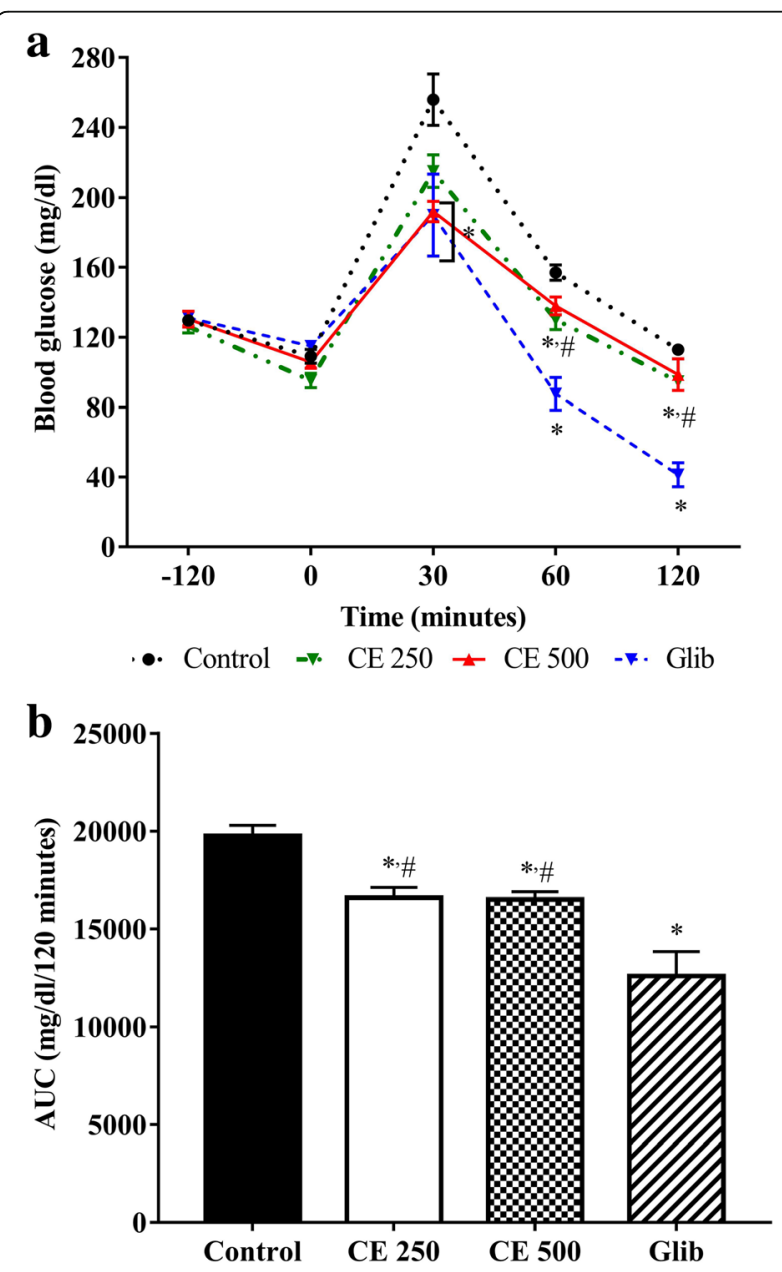

Fig. 2 Effect of C. cainito extract on OGTT in normal mice. Panel $\mathbf{a}$ is blood glucose level during oral glucose challenge whereas Panel $\mathbf{b}$ is the area under the curve (AUC) of the blood glucose level over time. ${ }^{*} P<0.05$ compared with control mice; ${ }^{\#} P<0.05$ compared with glibenclamide treated mice by one-way ANOVA followed by Student-Newman-Keuls as post hoc test. The values are expressed as mean \pm SEM, $n=6$. Glib: glibenclamide; CE: C. cainito extract 


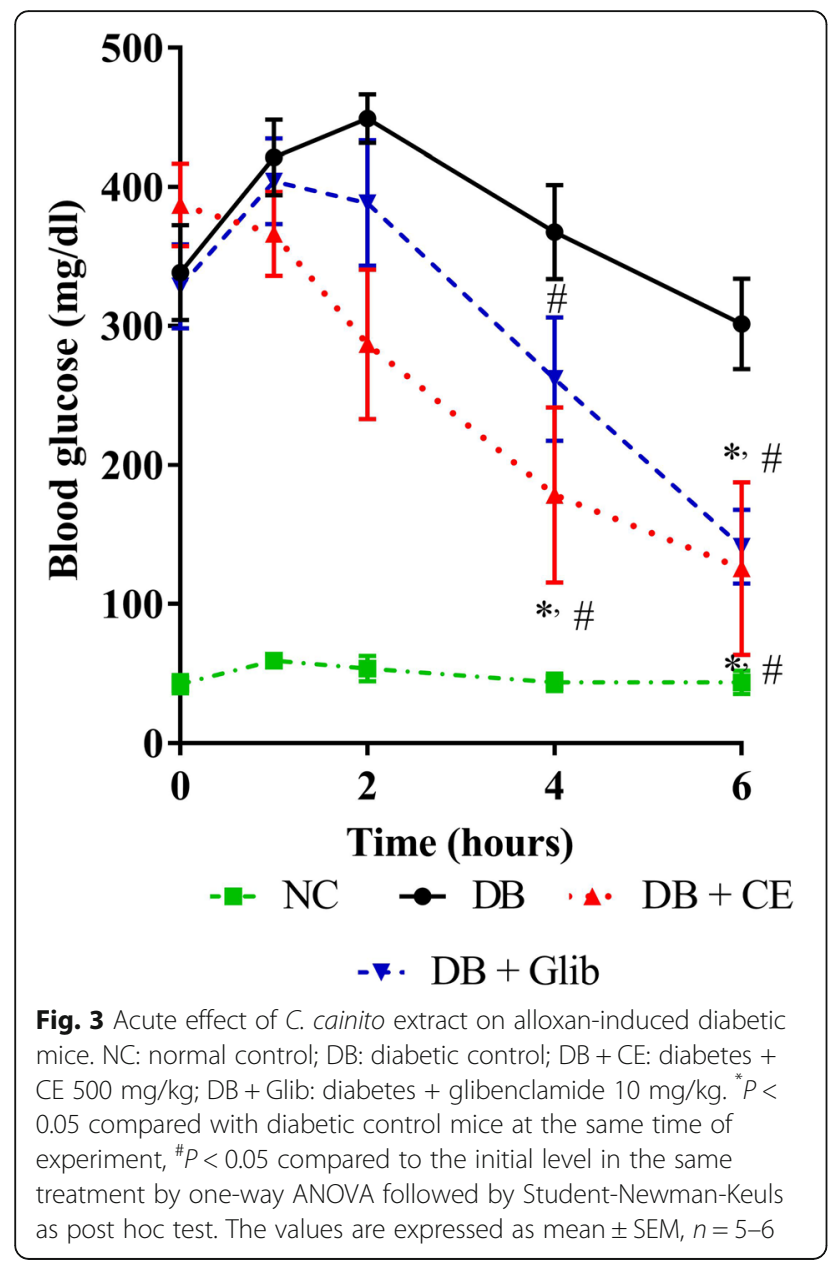

exhibited much greater inhibition on $\alpha$-glucosidase activity compared to acarbose. The $\mathrm{IC}_{50}$ of CE was 1.20 $\pm 0.09 \mu \mathrm{g} / \mathrm{ml}$ whereas that of acarbose was $198.17 \pm$ 4.74 $\mu \mathrm{g} / \mathrm{ml}$ (Fig. 6).

\section{Discussion}

It is widely accepted that the rapidly increasing incidence of diabetes mellitus has become a major health problem worldwide. The modern oral hypoglycemic agents such as sulphonylureas, biguanides, thiozolidinediones and $\alpha$-glucosidase inhibitors are commonly used for the treatment of type 2 diabetes. However, it is well known that they can produce side effects associated with their applications [25]. Moreover, a progressive decline in their effectiveness, termed secondary failure have been reported [26]. During the past decade, there is a growing interest in alternative herbal medicine due to their efficacy, less side effects in clinical practice and relatively low costs. It has been estimated that about 800 plants have antidiabetic potentials [27]. Most of them have been used as folk medicines in many countries around the world. C. cainito, commonly called Star Apple in English and Vú Sữa (literally: milky breast) in

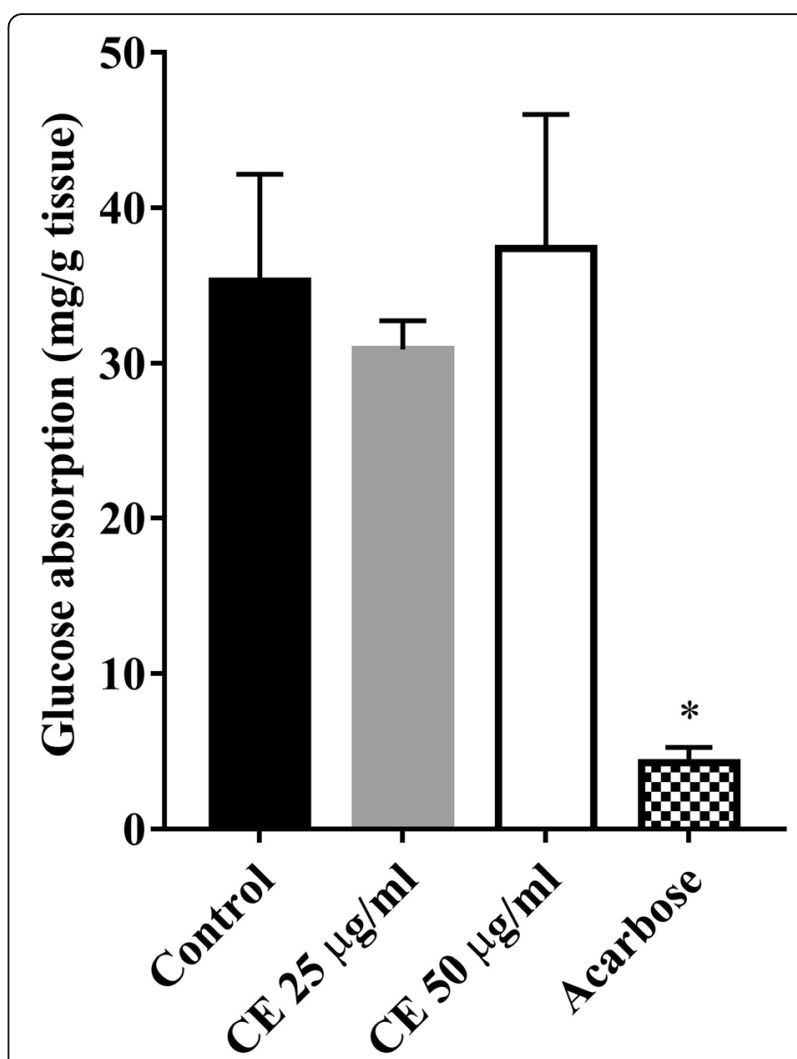

Fig. 4 The effect of C. cainito extract (CE) on glucose absorption by everted mouse jejunum. The values are expressed as mean $\pm \mathrm{SEM}, n$ $=5$. ${ }^{*} P<0.05$ compared to control by one-way ANOVA followed by Student-Newman-Keuls as post hoc test

Vietnamese, is one of medicinal plants which has long been prescribed by local practitioners for traditional treatment of diabetes mellitus. However, there is a paucity of scientific evidence that confirms its antidiabetic activity. Herein, we first evaluated the antidiabetic effect of the extract from $C$. cainito stem bark to confirm its benefits according to the use of this plant in Vietnam.

In this study, antidiabetic effect of the $C$. cainito extract was conducted in healthy and alloxan-diabetic mice. In normal mice, the hypoglycemic effect of the extract was investigated through an oral glucose tolerance test (OGTT). A 6-h fasting is considered as a best fasting duration for establishing an OGTT in mice [28]. The rise in blood glucose after $30 \mathrm{~min}$ confirmed successful oral glucose loading in every group (Fig. 2). The antidiabetic drug glibenclamide used in this study as a positive control reduces the postprandial hyperglycemia by increasing insulin secretion from $\beta$ cell. Based on our preliminary experiment, the dose at $500 \mathrm{mg} / \mathrm{kg}$ was chosen for oral administration. As shown in Fig. $2 \mathrm{a}$ and $b$, the extract and glibenclamide improved glucose tolerance compared to vehicle control. 


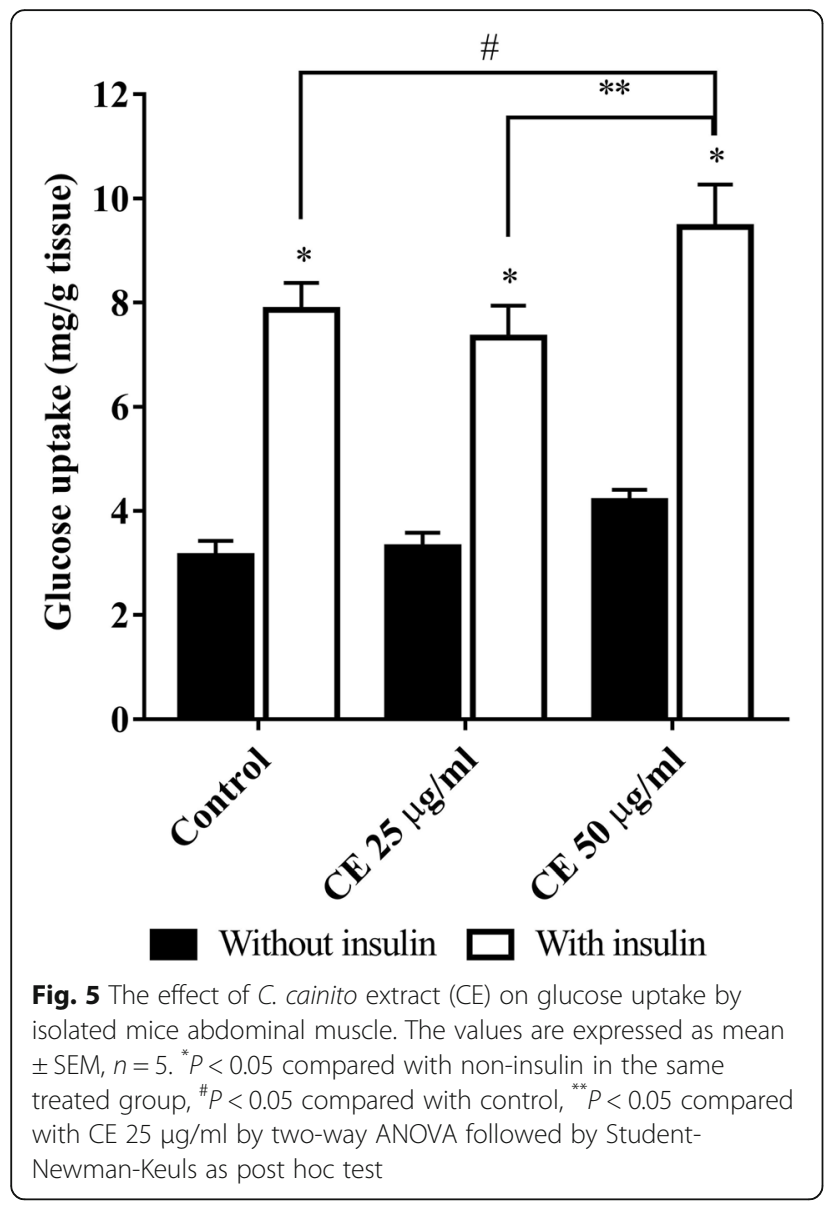

Alloxan, a toxic glucose analogue, enters pancreatic $\beta$-cell via GLUT2 glucose transporter. This chemical plays an important role in hyperglycemic animal model through its specific inhibition of glucokinase and stimulation of reactive oxygen species production, consequently causing necrosis and destruction of $\beta$-cells [29]. The data from Fig. 3 clearly showed that the administration of $\mathrm{CE}$ reduced blood glucose level in alloxan-induced diabetic mice similar to that of glibenclamide. These in vivo experiments provide the first scientific evidence supporting an anti-hyperglycemic activity of $C$. cainito stem bark.

Numerous mechanisms of action have been proposed for medicinal plants used in the treatment of diabetes mellitus. However, none has been postulated for antidiabetic activity of $C$. cainito. In this study, two possible mechanisms underlying its acute antidiabetic activity, an inhibition of glucose absorption and a stimulation of glucose uptake were examined. The glucose absorption was performed using everted jejunal sacs of mice. Acarbose, a well-known $\alpha$-glucosidase inhibitor currently used for the treatment of diabetic patients, was used as a positive control because it has been shown to additionally inhibit the absorption of D-glucose from the intestinal lumen into the blood stream $[23,30]$. The data

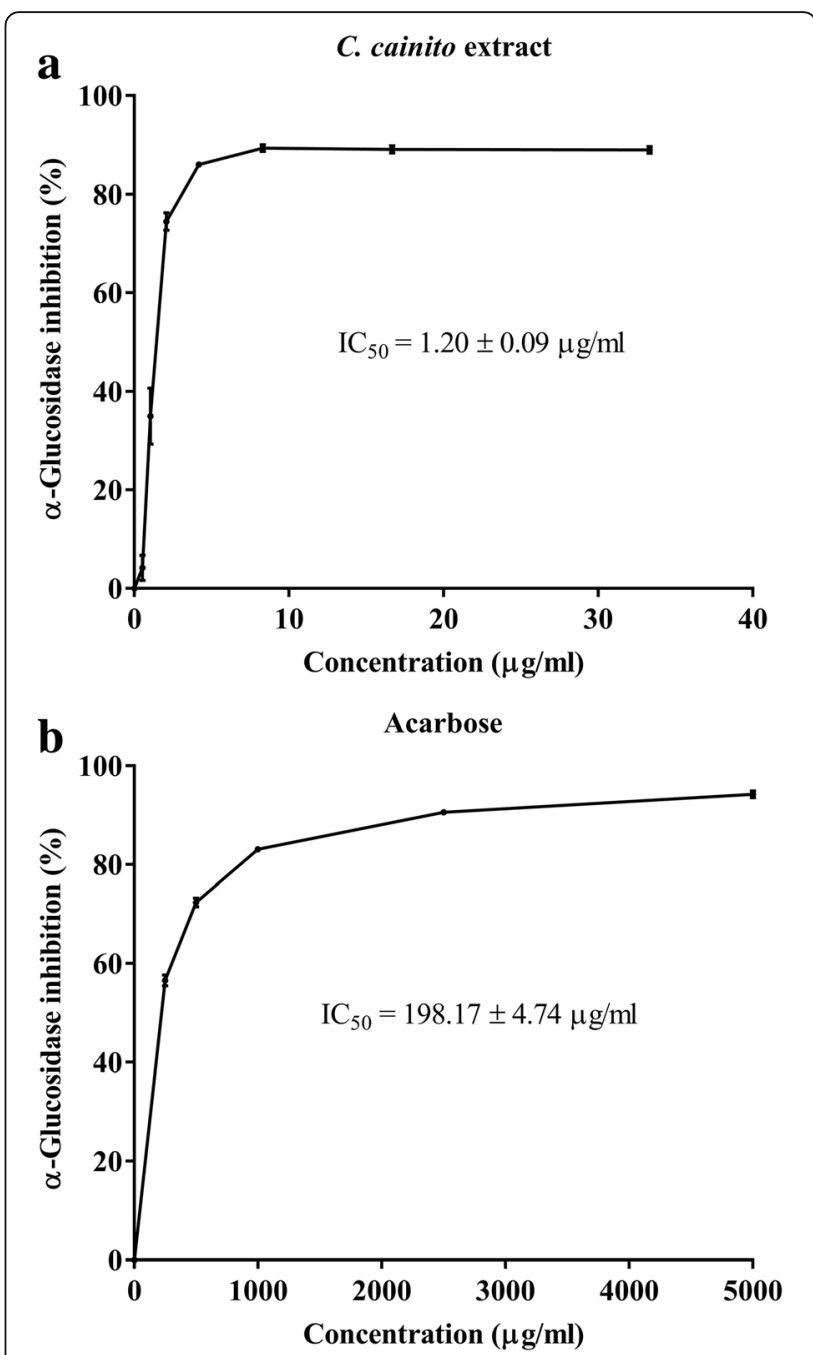

Fig. 6 The effect of C. cainito extract (CE) on a-glucosidase activity. Values are expressed as mean \pm S.E.M. of three separate experiments. Acarbose was used as positive control. Panel $\mathbf{a}$ and $\mathbf{b}$ are results from a-glucosidase inhibitory activities of $C$. cainito and acarbose, respectively. The calculated $I C_{50}$ of the extract was $1.20 \pm 0.09 \mu \mathrm{g} / \mathrm{ml}$, whereas that of acarbose was $198.17 \pm 4.74 \mu \mathrm{g} / \mathrm{ml}$

in Fig. 4 showed that unlike acarbose, CE did not inhibit the glucose absorption.

Isolated skeletal muscle such as epitrochlearis muscle [31, 32] and abdominal muscle [24, 33, 34] have been exploited in the glucose uptake study. In the current study, we isolated the abdominal muscle from mice and incubated in a bicarbonate buffer with carbogen supplied constantly. The effect of CE on glucose uptake was evaluated in the absence and presence of insulin. The data in Fig. 5 shows that in the presence of insulin $\mathrm{CE}$ at $50 \mu \mathrm{g} / \mathrm{ml}$ significantly enhanced glucose uptake by the muscle $(9.45 \pm 0.82 \mathrm{mg} / \mathrm{g}$ tissue) compared to control $(7.86 \pm 0.52 \mathrm{mg} / \mathrm{g}$ tissue). Without insulin, CE treatment also showed an increase of glucose uptake, but not statistical significant. These in vitro experiments revealed 
that the extract promoted glucose transport in the skeletal muscle, especially in the presence of insulin, but no effect on glucose absorption. It is likely that the enhancement on glucose uptake contributes to the antidiabetic effect of CE.

In this study, the in vivo experiments were done only in the acute treatment mainly to provide scientific evidence to support the hypoglycemic activity of the extract. One may argue that the postulated action on glucose uptake in this study could not explain the acute anti-hyperglycemic effect of the extract. Skeletal muscle is recognized as the major site of insulin-mediated glucose uptake after carbohydrate consumption in human [35]. Insulin resistance is a hallmark of non-insulin dependent diabetic mellitus. Peroxisome proliferator-activated receptor gamma (PPAR $\gamma$ ) is a key factor in insulin sensitivity. The activation of PPAR $\gamma$ by insulin sensitizers (e.g. thiazolidinediones) markedly improve the sensitivity to insulin, however, it requires long-term effect to cause gene expression change [36]. Moreover, PPAR $\gamma$ is prominently present in adipose tissue and nearly absent in muscle [37]. The enhancement of insulin action in skeletal muscle by $\mathrm{CE}$ found in this study tend to be mediated via other mechanism(s).

It is well established that glucose uptake by skeletal muscle is mostly via glucose transporter 4 (GLUT4). It has been shown that GLUT4 recruitment from cytosol to the cell surfaces of muscle can be acutely stimulated by both insulin and exercise independent of transcription or translation $[38,39]$. The translocation of GLUT4 from intracellular vesicles to accumulate in the plasma membrane in the response to insulin was demonstrated to depend on the activation of the insulin receptor substrate 1, PI3K, PDK1 and Akt2 [40]. In addition, the data from a previous study suggested that an acute stimulation effect on insulin-mediated glucose uptake in skeletal muscle was related to the elevation of the phosphorylation and activation of key proteins involving in the translocation of GLUT4 such as Rac1, AS160 and Akt [41]. Other studies suggested that the rising in glucose uptake was due to the increase of AMPK phosphorylation [31, 42]. This pathway supports the acute anti-hyperglycemic effect of the CE by increasing glucose uptake in the muscle.

$\alpha$-Glucosidase is a digestive enzyme which catalyzes the breakdown of polysaccharides into monosaccharide, the form of carbohydrate that the intestine can only be able to transport into the blood circulation. Therefore, the inhibition of $\alpha$-glucosidase is one of the important approaches in oral antidiabetic medication. Reducing postprandial glucose level by delay glucose absorption after meal is the prominent benefit from $\alpha$-glucosidase inhibitor [43]. In addition to the glucose uptake stimulation which is proposed as a mechanism underlying the acute hypoglycemic effect of $C$. cainito extract in this study, $\alpha$-glucosidase inhibitory effect was also investigated. The $\mathrm{IC}_{50}$ value of the extract was found at $1.20 \pm$ $0.09 \mu \mathrm{g} / \mathrm{ml}$, approximately 200 times lower than that of acarbose which is used clinically as antidiabetic drug. Although this action could not be attributed to the anti-hyperglycemic mechanism in this study, it could be anticipated to contribute to the blood lowering effect when used as alternative medicine in diabetic patients. Moreover, this plant could be a potential candidate for a search of a new $\alpha$-glucosidase inhibitory drug for diabetic care.

Free radicals are found to be associated with many diseases, including diabetes. In diabetes mellitus, the supplement of antioxidant agents show promising effect on the reverse of the oxidative stress biomarkers and diabetic complications [3]. Major antioxidant ability can be classified into two groups, hydrogen atom transfer and single electron transfer based assays. For in vitro antioxidant measurement, a single assay may not provide sufficient evidence for antioxidant potential of a compound. Therefore, in this study, the antioxidant activity of $\mathrm{CE}$ was assessed by different methods including DPPH, ABTS, and FRAP assays. DPPH, a stable organic nitrogen radical, is used to perform a simple technique assay. DPPH assay has been considered as a valid accurate and easy method to determine radical scavenging activity of antioxidants. However, the disadvantages of this method are (1) the cross interaction between DPPH radical and other radicals and (2) the time response curve to reach the final stable state is not linear with different ratios of antioxidant and DPPH [44]. In ABTS assay, the oxidant was generated by the reaction between ABTS ammonium and potassium persulfate. This assay has been used commonly in many laboratories although it costs time to prepare the radical. The FRAP assay is an electron transfer based assay. The oxidant involves many Fe (III) species and many metal chelators in food extract. The redox potential of Fe (III) salt in FRAP assay is comparable to ABTS ${ }^{\circ}$ in ABTS assay [45]. As shown in Table 2, the results from all methods used in this study were in agreement that the extract had quite strong antioxidant activity.

Phytochemical analysis of CE obtained from this study showed the presence of phenols, tannin, glycosides, terpenoids, and saponin of which the antidiabetic effects have been established [46-49]. The extract contains great amounts of phenolic compounds (871.75 \pm $10.41 \mathrm{mg}$ GAE/g extract) and had high antioxidant potential comparable to antioxidant power of the standard antioxidant ascorbic acid and butylated hydroxytoluene (Table 2). These results agree with previous report that high phenolic content was correlated with strong antioxidant activity [48]. It can be anticipated that the 
antioxidant activity of $\mathrm{CE}$ may be beneficial in the long-term treatment of diabetic patients. Nine polyphenolic compounds, (+)-catechin, (+)-gallocatechin, (-)-epigallocatechin, quercetin, quercitrin, isoquercitrin, myricitrin, gallic acid and (-)-epicatechin were isolated from fruit of $C$. cainito [49]. Others including ursolic acid, $\beta$-sitosterol, lupeol and gallic acid were extracted from the leaves [50]. It has been demonstrated that these compounds possess antidiabetic activity [51-54]. In terms of the compositions of $C$. cainito stem bark, there is lack of information. Phytochemical verification and identification of the active ingredients responsible for its antidiabetic activity need further investigation.

\section{Conclusion}

In conclusion, the aqueous extract from $C$. cainito stem bark possesses a strong in vitro antioxidant activity and in vivo antidiabetic effects. It is postulated that the mechanism of action contributing the acute anti-hyperglycemic effect of the extract is the enhancement of glucose uptake by the muscles. Moreover, the extract was also found to possess strong $\alpha$-glucosidase inhibitory effect which may contribute to its anti-hyperglycemic action when used in diabetic patients. The results obtained in the present study provide scientific rationale to corroborate the use of $C$. cainito stem bark for its traditional diabetic treatment.

\section{Abbreviations}

AA: Ascorbic acid; ABTS: 2,2'-azino-bis (3-ethylbenzothiazoline-6-sulfonic acid) diammonium salt; BHT: Butylated hydroxytoluene; CE: C. cainito extract; DPPH: 2,2-diphenyl-1-picrylhydrazyl; FRAP: Ferric reducing antioxidant power; GAE: Gallic acid equivalent; KRB: Kreb's-Ringer bicarbonate; OGTT: Oral glucose tolerance test; PGO: Peroxidase-glucose oxidase

\section{Acknowledgements}

The authors would like to extend their appreciation to the Office of the Higher Education Commission under NRU Project of Thailand and Suranaree University of Technology (SUT) for partial financial support (salary for researcher assistant, RI). We are thankful to Dr. Santi Watthana for plant verification.

\section{Availability data and materials}

All datasets generated and/or analyzed during this study are available from the corresponding author on reasonable request.

\section{Funding}

Suranaree University of Technology for its funding of this research under the SUT-PhD Scholarship program for ASEAN.

\section{Authors' contributions \\ HVD conceived the study and performed the experiments. He contributed to the interpretation, analysis of the data and drafted the manuscript. SR and RI participated in the performing of the animal experiments and in vitro studies. NC supervised the experimental design and data analysis. She revised the manuscript for submission. All authors read and approved the final manuscripts.}

\section{Ethics approval}

All animal procedures were approved and conducted following the guidelines of the Institutional Animal Care and Use Committee, Suranaree University of Technology, Thailand (No. 1/2561).

\section{Consent for publication}

Not applicable

\section{Competing interests}

The authors declared that they have no competing interests.

\section{Publisher's Note}

Springer Nature remains neutral with regard to jurisdictional claims in published maps and institutional affiliations.

Received: 14 March 2018 Accepted: 20 September 2018

Published online: 01 October 2018

\section{References}

1. Ogurtsova K, da Rocha Fernandes JD, Huang Y, Linnenkamp U, Guariguata L, Cho NH, et al. IDF diabetes atlas: global estimates for the prevalence of diabetes for 2015 and 2040. Diabetes Res Clin Pract. 2017;128:40-50.

2. Fowler MJ. Microvascular and macrovascular complications of diabetes. Clin Diabetes. 2008:26:77-82.

3. Johansen JS, Harris AK, Rychly DJ, Ergul A. Oxidative stress and the use of antioxidants in diabetes: linking basic science to clinical practice. Cardiovasc Diabetol. 2005:4:5.

4. Pietta P, Simonetti $P$, Mauri P. Antioxidant activity of selected medicinal plants. J Agric Food Chem. 1998:46:4487-90

5. Krishnaiah D, Sarbatly R, Nithyanandam R. A review of the antioxidant potential of medicinal plant species. Food Bioprod Process. 2011;89:217-33.

6. Yashwant Kumar A, Nandakumar K, Handral M, Talwar S, Dhayabaran D. Hypoglycaemic and anti-diabetic activity of stem bark extracts Erythrina indica in normal and alloxan-induced diabetic rats. Saudi Pharm J. 2011;19:35-42.

7. Meira NA, Klein LCJ, Rocha LW, Quintal ZM, Monache FD, Cechinel Filho V, et al. Anti-inflammatory and anti-hypersensitive effects of the crude extract, fractions and triterpenes obtained from Chrysophyllum cainito leaves in mice. J Ethnopharmacol. 2014;151:975-83.

8. Shailajan S, Gurjar D. Wound healing activity of Chrysophyllum cainito L. leaves: evaluation in rats using excision wound model. J Young Pharm. 2016;8:96-103.

9. Oranusi SU, Braide W, Umeze RU. Antimicrobial activities and chemical compositions of Chrysophyllum cainito (star apple) fruit. Ambit J. 2015;1:8-24.

10. Koffi N, Ernest AK, Marie-Solange T, Beugre K, Noeuml ZG. L. Effect of aqueous extract of Chrysophyllum cainito leaves on the glycaemia of diabetic rabbits. African J Pharm Pharmacol. 2009;3:501-6.

11. Hegde K, Arathi A, Mathew A. Evaluation of antidiabetic activity of hydro alcoholic extract of Chrysophyllum cainito fruits. Int J Pharm Sci Res. 2016;7:4422-8.

12. Morton JF. The star apple. In: Fruits of Warm Climates. Miami: Julia F. Morton; 1987. p. 408-10.

13. Koffi N, Konan Édouard K, Kouassi K. Ethnobotanical study of plants used to treat diabetes, in traditional medicine, by Abbey and Krobou people of Agboville (Côte-d'Ivoire). Am J Sci Res. 2009;2009:45-58.

14. Yadav RNS, Agarwala M. Phytochemical analysis of some medicinal plants. J Phytol. 2011;3:10-4.

15. Sharma V, Paliwal R. Preliminary phytochemical investigation and thin layer chromatography profiling of sequential extracts of Moringa oleifera pods. Int J Green Pharm. 2013:7:41-5.

16. Kumkrai P, Weeranantanapan O, Chudapongse N. Antioxidant, a-glucosidase inhibitory activity and sub-chronic toxicity of Derris reticulata extract: its antidiabetic potential. BMC Complement Altern Med. 2015:15:35.

17. Abdennacer B, Karim M, Yassine M, Nesrine R, Mouna D, Mohamed B. Determination of phytochemicals and antioxidant activity of methanol extracts obtained from the fruit and leaves of Tunisian Lycium intricatum Boiss. Food Chem. 2015:174:577-84

18. Sudan R, Bhagat M, Gupta S, Singh J, Koul A. Iron (Fell) chelation, ferric reducing antioxidant power, and immune modulating potential of Arisaema jacquemontii (Himalayan cobra lily). Biomed Res Int. 2014;2014:179865.

19. Ibrahim MA, Islam MS. Butanol fraction of Khaya senegalensis root modulates beta-cell function and ameliorates diabetes-related biochemical parameters in a type 2 diabetes rat model. J Ethnopharmacol. 2014;154:832-8.

20. Alam MM, Meerza D, Naseem I. Protective effect of quercetin on hyperglycemia, oxidative stress and DNA damage in alloxan induced type 2 diabetic mice. Life Sci. 2014;109:8-14.

21. Shahid S, Bukhari I, Abbasi MH, Ahmad MK. Dose optimization of alloxan for diabetes in albino mice. Biologica. 2015;61:301-5. 
22. Parra-Naranjo A, Delgado-Montemayor C, Fraga-López A, CastañedaCorral G, Salazar-Aranda R, Acevedo-Fernández JJ, et al. Acute hypoglycemic and antidiabetic effect of teuhetenone a isolated from Turnera diffusa. Molecules. 2017;22:559.

23. Widyawati T, Yusoff AN, Asmawi ZM, Ahmad M. Antihyperglycemic effect of methanol extract of Syzygium polyanthum (Wight.) leaf in streptozotocininduced diabetic rats. Nutrients. 2015;7(9):7764-80.

24. Hassan Z, Yam MF, Ahmad M, Yusof APM. Antidiabetic properties and mechanism of action of Gynura procumbens water extract in streptozotocininduced diabetic rats. Molecules. 2010;15:9008-23.

25. Fowler MJ. Diabetes treatment, part 2: Oral agents for glycemic management. Clin Diabetes. 2007;25:131-4.

26. Groop LC, Pelkonen R, Koskimies S, Bottazzo GF, Doniach D. Secondary failure to treatment with oral antidiabetic agents in non-insulin-dependent diabetes. Diabetes Care. 1986;9:129-33.

27. Grover JK, Yadav S, Vats V. Medicinal plants of India with anti-diabetic potential. J Ethnopharmacol. 2002;81:81-100

28. Andrikopoulos S, Blair AR, Deluca N, Fam BC, Proietto J. Evaluating the glucose tolerance test in mice. Am J Physiol Endocrinol Metab. 2008;295:E1323-32.

29. Lenzen S. The mechanisms of alloxan- and streptozotocin-induced diabetes. Diabetologia. 2008;51:216-26.

30. Hirsh AJ, Yao SY, Young JD, Cheeseman Cl. Inhibition of glucose absorption in the rat jejunum: a novel action of alpha-D-glucosidase inhibitors. Gastroenterology. 1997;113:205-11.

31. Ma X, Iwanaka N, Masuda S, Karaike K, Egawa T, Hamada T, et al. Morus alba leaf extract stimulates 5'-AMP-activated protein kinase in isolated rat skeletal muscle. J Ethnopharmacol. 2009;122:54-9.

32. Kleinert M, Liao Y-H, Nelson JL, Bernard JR, Wang W, Ivy JL. An amino acid mixture enhances insulin-stimulated glucose uptake in isolated rat epitrochlearis muscle. J Appl Physiol. 2011;111:163-9.

33. O'Harte FP, Gray AM, Flatt PR. Gastric inhibitory polypeptide and effects of glycation on glucose transport and metabolism in isolated mouse abdominal muscle. J Endocrinol. 1998;156:237-43.

34. Boyd AC, Abdel-Wahab YH, McKillop AM, McNulty H, Barnett CR, O'Harte FP, et al. Impaired ability of glycated insulin to regulate plasma glucose and stimulate glucose transport and metabolism in mouse abdominal muscle. Biochim Biophys Acta. 2000;1523:128-34.

35. DeFronzo RA, Tripathy D. Skeletal muscle insulin resistance is the primary defect in type 2 diabetes. Diabetes Care. 2009;32:S157-63.

36. Olefsky JM. Treatment of insulin resistance with peroxisome proliferatoractivated receptor $\gamma$ agonists. J Clin Invest. 2000;106:467-72.

37. Ferré $P$. The biology of peroxisome proliferator-activated receptors. Diabetes. 2004;53:543-50.

38. Herman MA, Kahn BB. Glucose transport and sensing in the maintenance of glucose homeostasis and metabolic harmony. J Clin Invest. 2006;116:1767-75.

39. Rose AJ, Richter EA. Skeletal muscle glucose uptake during exercise: how is it regulated? Physiology. 2005;20:260-70.

40. Satoh T. Molecular mechanisms for the regulation of insulin-stimulated glucose uptake by small guanosine triphosphatases in skeletal muscle and adipocytes. Int J Mol Sci. 2014;15:18677-92.

41. Röhling M, Herder C, Stemper T, Müssig K. Influence of acute and chronic exercise on glucose uptake. J Diabetes Res. 2016;2016:2868652.

42. Vlavcheski F, Naimi M, Murphy B, Hudlicky T, Tsiani E. Rosmarinic acid, a rosemary extract polyphenol, increases skeletal muscle cell glucose uptake and activates AMPK. Molecules. 2017:22:E1669.

43. Mohamed EAH, Siddiqui MJA, Ang LF, Sadikun A, Chan SH, Tan SC, et al. Potent a-glucosidase and a-amylase inhibitory activities of standardized 50\% ethanolic extracts and sinensetin from Orthosiphon stamineus Benth as anti-diabetic mechanism. BMC Complement Altern Med. 2012;12:176.

44. Kedare SB, Singh RP. Genesis and development of DPPH method of antioxidant assay. J Food Sci Technol. 2011;48:412-22.

45. Huang D, Ou B, Prior RL. The chemistry behind antioxidant capacity assays. J Agric Food Chem. 2005;53:1841-56.

46. Abdallah HM, Salama MM, Abd-elrahman EH, El-Maraghy SA. Antidiabetic activity of phenolic compounds from pecan bark in streptozotocin-induced diabetic rats. Phytochem Lett. 2011:4:337-41.

47. Nazaruk J, Borzym-Kluczyk M. The role of triterpenes in the management of diabetes mellitus and its complications. Phytochem Rev. 2015;14:675-90.

48. Piluzza G, Bullitta S. Correlations between phenolic content and antioxidant properties in twenty-four plant species of traditional ethnoveterinary use in the Mediterranean area. Pharm Biol. 2011;49:240-7.
49. Luo XD, Basile MJ, Kennelly EJ. Polyphenolic antioxidants from the fruits of Chrysophyllum cainito L. (star apple). J Agric Food Chem. 2002;50:1379-82.

50. Shailajan S, Gurjar D. Pharmacognostic and phytochemical evaluation of Chrysophyllum cainito Linn. leaves. Int J Pharm Sci Rev Res. 2014;26:106-11.

51. Castro AJG, Frederico MJS, Cazarolli LH, Mendes CP, Bretanha LC, Schmidt ÉC, et al. The mechanism of action of ursolic acid as insulin secretagogue and insulinomimetic is mediated by cross-talk between calcium and kinases to regulate glucose balance. Biochim Biophys Acta. 2015;1850:51-61.

52. Gupta R, Sharma AK, Dobhal MP, Sharma MC, Gupta RS. Antidiabetic and antioxidant potential of beta-sitosterol in streptozotocin-induced experimental hyperglycemia. J Diabetes. 2011;3:29-37.

53. Gupta R, Sharma AK, Sharma MC, Dobhal MP, Gupta RS. Evaluation of antidiabetic and antioxidant potential of lupeol in experimental hyperglycaemia. Nat Prod Res. 2012;26:1125-9.

54. Oboh G, Ogunsuyi OB, Ogunbadejo MD, Adefegha SA. Influence of gallic acid on a-amylase and a-glucosidase inhibitory properties of acarbose. J Food Drug Anal. 2016;24:627-34.
Ready to submit your research? Choose BMC and benefit from:

- fast, convenient online submission

- thorough peer review by experienced researchers in your field

- rapid publication on acceptance

- support for research data, including large and complex data types

- gold Open Access which fosters wider collaboration and increased citations

- maximum visibility for your research: over $100 \mathrm{M}$ website views per year

At $\mathrm{BMC}$, research is always in progress.

Learn more biomedcentral.com/submissions 